\title{
Cellular factors involved in HTLV-1 entry and pathogenicity
}

\author{
Hiroo Hoshino* \\ Advanced Scientific Research-Leaders Development Unit, Gunma University Graduate School of Medicine, Maebashi, Gunma, Japan
}

\section{Edited by:}

Yasuko Yokota, National Institute of

Infectious Diseases, Japan

\section{Reviewed by:}

Dorian Mcllroy, University of Nantes, France

Jun-Ichi Fujisawa, Kansai Medical

University, Japan

\section{*Correspondence}

Hiroo Hoshino, Advanced Scientific Research-Leaders Development Unit, Gunma University Graduate School of Medicine, Showa-machi, Maebashi, Gunma 371-8511, Japan.

e-mail: hoshino@gunma-u.ac.jp
Human T cell leukemia virus type 1 (HTLV-1) is the causative agent of adult T cell leukemia (ATL) and HTLV-1 - associated myelopathy and tropical spastic paraparesis (HAM/TSP). HTLV-1 has a preferential tropism for CD4T cells in healthy carriers and ATL patients, while both CD4 and CD8 T cells serve as viral reservoirs in HAM/TSP patients. HTLV- 1 has also been detected other cell types, including monocytes, endothelial cells, and dendritic cells. In contrast to the limited cell tropism of HTLV-1 in vivo, the HTLV receptor appears to be expressed in almost all human or animal cell lines. It remains to be examined whether this cell tropism is determined by host factors or by HTLV-1 heterogeneity. Unlike most retroviruses, cell-free virions of HTLV-1 are very poorly infectious. The lack of completely HTLV-1-resistant cells and the low infectivity of HTLV-1 have hampered research on the HTLV entry receptor. Entry of HTLV-1 into target cells is thought to involve interactions between the env (Env) glycoproteins, a surface glycoprotein (surface unit), and a transmembrane glycoprotein. Recent studies have shown that glucose transporter GLUT1, heparan sulfate proteoglycans (HSPGs), and neuropilin-1 (NRP-1) are the three proteins important for the entry of HTLV-1. Studies using adherent cell lines have shown that GLUT1 can function as a receptor for HTLV. HSPGs are required for efficient entry of HTLV-1 into primary CD4 T cells. NRP-1 is expressed in most established cell lines. Further studies have shown that these three molecules work together to promote HTLV-1 binding to cells and fusion of viral and cell membranes. The virus could first contact with HSPGs and then form complexes with NRP-1, followed by association with GLUT1. It remains to be determined whether these three molecules can explain HTLV-1 cell tropism. It also remains to be more definitively proven that these molecules are sufficient to permit HTLV-1 entry into completely HTLV-1-resistant cells.

Keywords: epidemiology, cell tropism, heparan sulfate, glucose transporter GLUT1, neuropilin-1, syncytia formation, Env proteins, Env isomerization

\section{INTRODUCTION}

Human T cell leukemia virus type 1 (HTLV-1) or T-lymphotrophic virus type 1 is a member of the deltaretrovirus family, which includes the simian T-lymphotrophic virus type 1 (STLV-1) and bovine leukemia virus (BLV). There are four known strains of HTLV, i.e., HTLV-1, HTLV-2, HTLV-3, and HTLV-4. HTLV-1 and HTLV-2 are prevalent worldwide (Edlich et al., 2000; Proietti et al., 2005), while HTLV-3 and HTLV-4 have been identified only in Central Africa (Mahieux and Gessain, 2009). HTLV-1 and STLV1 are highly related; HTLV-2 and HTLV-3 are closely related to STLV-2 and STLV-3, respectively. Thus, the HTLVs are thought to derive from interspecies transmission between monkeys and humans. The genetic variation among HTLV-1 strains is less than $8 \%$, and HTLV-1 and HTLV-2 show 70\% nucleotide homology (Gessain et al., 1996; Feuer and Green, 2005).

Human T cell leukemia virus type 1 was first isolated in 1980 in a $\mathrm{T}$ cell line derived from a patient with cutaneous $\mathrm{T}$ cell lymphoma (Poiesz et al., 1980) and was shown to be the etiological agent of adult T cell leukemia (ATL; Hinuma et al., 1981; Yoshida et al., 1982; Takatsuki, 2005). In 1985, HTLV-1-seropositive patients in French Martinique were diagnosed with a neurodegenerative disorder, termed tropical spastic paraparesis (TSP; Gessain et al.,
1985). A similar clinical disorder was reported in Japanese patients and was named HTLV-1 associated myelopathy (HAM; Osame et al., 1986; Osame and Igata, 1989). HTLV-2 is rarely pathogenic and is sporadically associated with neurological disorders (Hjelle et al., 1992; Araujo and Hall, 2004). There have been no known diseases associated with HTLV-3 or HTLV-4.

Here, the results from in vivo and in vitro studies concerning HTLV-1 infection, focusing on the mechanisms of HTLV-1 entry, are reviewed.

\section{EPIDEMIOLOGY OF HTLV-1 INFECTION}

An estimated 15-20 million persons are infected with HTLV-1 throughout the world. The virus is endemic in southwestern Japan, Central Africa, the Caribbean Islands, and Australia (aborigines) as well as in some regions of South America, Melanesia, Middle East, and India. Thus, HTLV-1 prevalence shows a quite strange ethnic distribution. In these endemic areas, the seroprevalence rates range from 0.1 to 30\% (Blattner et al., 1982; Saxinger et al., 1984; Yanagihara et al., 1990; Gotuzzo et al., 2000; Sonoda et al., 2011). After prolonged latency periods of $40-60$ years, approximately $5 \%$ of HTLV-1-infected individuals ( $6.6 \%$ of males and $2.1 \%$ of females) will develop ATL (Kajiyama et al., 1986; Murphy et al., 1989; Edlich 
et al., 2000; Proietti et al., 2005; Sonoda et al., 2011). HTLV-2 is prevalent among intravenous drug users (IDUs) and is endemic among IDUs in the USA, Europe, South America, and Southeast Asia (Lee et al., 1989; Khabbaz et al., 1992; Fukushima et al., 1995).

Human $\mathrm{T}$ cell leukemia virus type 1 is transmitted through three major routes: (1) breastfeeding from mother-to-child, (2) sexual contact from male to female, and (3) needle sharing which mediates exposure to contaminated blood. Mother-to-child transmission through breastfeeding is the predominant mode. Transmission rates are approximately $20 \%$ for children born to infected mothers. Lifetime sexual transmission rates between spouses are $60 \%$ from infected males to females and only $0.4 \%$ from infected females to males (Kajiyama et al., 1986; Kusuhara et al., 1987; Murphy et al., 1989; Hino et al., 1994; Ureta-Vidal et al., 1999; Sonoda et al., 2011). These epidemiological characteristics of HTLV-1 infection are, or shall be, associated with virological properties of HTLV-1 that have been, or will be, clarified in vitro.

\section{STRUCTURE AND GENE PRODUCTS OF HTLV-1 GENOME}

Human $\mathrm{T}$ cell leukemia virus type 1 is an enveloped virus of approximately $100 \mathrm{~nm}$ in diameter. Newly synthesized viral particles attach to target cell receptors on the viral envelope (Env) and enter the target cell through membrane fusion. Entry is followed by capsid uncoating and content release into the cell cytoplasm. The viral RNA is reverse transcribed into double-stranded DNA by reverse transcriptase (RT), which is then transported to the nucleus and integrated into the host chromosome, forming the provirus.

Human T cell leukemia virus type 1 is a single-stranded diploid RNA virus, and the proviral genome of HTLV-1 is 9,030-9,040 nucleotides long containing two flanking long terminal repeat (LTR) sequences (Figure 1; Seiki et al., 1983). The LTRs of HTLV-1 comprise three components: a unique $3^{\prime}$ (U3) region, a repeated (R) region, and a unique $5^{\prime}$ (U5) region. The HTLV-1 genome is packaged in the viral core with the viral nucleocapsid protein ( $\mathrm{p} 15$ NC), which is surrounded by capsid (p24 CA) and matrix (p19 MA) proteins.

The HTLV-1 genome encodes the structural proteins Gag (NC, $\mathrm{CA}$, and MA) and Env and the enzymes RT, RNase H (RH), integrase (IN), and protease (Pro; Figure 1). The env gene encodes

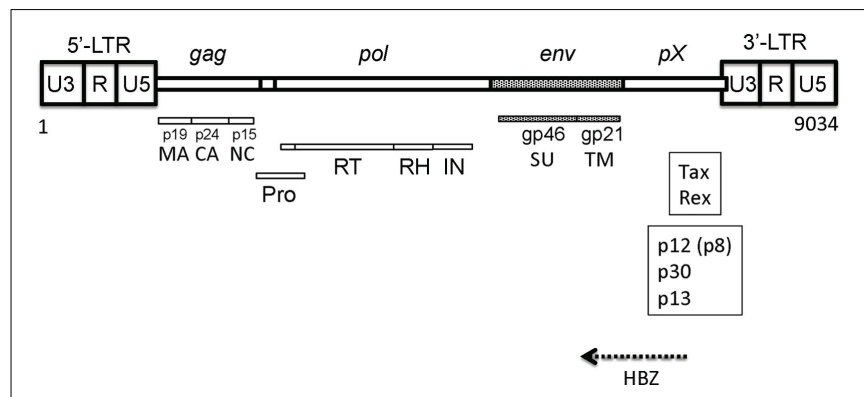

FIGURE 1 | Structure of HTLV-1 genome. The gag gene encodes the matrix (MA), capsid (CA), and nucleocapsid (NC) proteins. The pol gene encodes reverse transcriptase (RT), RNase $H(R H)$, and integrase (IN). The $p X$ region encodes $p 13, p 12, p 30$, etc. HBZ is encodes by the anti-sense frame of the provirus. the surface unit (SU) gp46 and transmembrane unit (TM) gp21 proteins (Hattori et al., 1984; Figure 2).

The envelope is made of a lipid bilayer of cellular origin, which contains the virally encoded Env glycoproteins. The Env proteins are synthesized as a precursor protein, gp62, and cleaved into the gp46 and gp 21 glycoprotein subunits. The SU protein gp46 is associated with the TM gp21, and the SU-TM complex is anchored to the viral or infected cell membrane through the membranespanning region (MSR) within TM (Figures 3 and 4). HTLV-1 Env is a trimer of the gp46-gp21 subunit pair. Cell receptor-binding activity is conferred by gp46 and the fusion activity is a function of gp21. The HTLV-1 Env proteins are genetically highly conserved among isolates, and the variability within their amino acid sequences ranges from 1 to 8\% (Gessain et al., 1996; Feuer and Green, 2005).

The pX region encodes the accessory proteins as well as the regulatory proteins Tax and Rex (Sodroski et al., 1984; Cann et al., 1985; Felber et al., 1985; Fujisawa et al., 1985; Figure 1). The accessory genes are alternatively spliced and translated from different initiation sites. These genes encode novel proteins, such as $\mathrm{p} 12 / \mathrm{p} 8$, p30, and p13 (Albrecht et al., 2000; Silverman et al., 2004; Nicot et al., 2005). The anti-sense region corresponding to the $\mathrm{pX}$ region and the env gene region encodes HBZ (Gaudray et al., 2002; Arnold et al., 2006; Matsuoka and Jeang, 2011; Figure 1). The expression of the HBZ gene has been detected in primary leukemic cells isolated from all ATL patients tested while the tax transcript was hardly detectable in them. The HBZ gene has growth-promoting activity in vivo and in vitro. These findings suggest that HBZ gene transcription is indispensable for the development of ATL.

\section{CELLS INFECTED WITH HTLV-1 IN VIVO}

Approximately up to 5\% of HTLV-1-infected patients will develop ATL after a prolonged latency period (Uchiyama, 1997; Takatsuki, 2005; Sonoda et al., 2011). In vivo, the targets of virusinduced transformation are CD4+/CD45RO+ memory $\mathrm{T}$ cells. A monoclonal population of T cells showing CD3+/CD4+/CD8/CD25+/HLA-DR+/CCR4+ cell surface markers also characterizes malignant cells of ATL (Uchiyama, 1997; Suzuki et al., 1998; Takatsuki, 2005; Hieshima et al., 2008). Regulatory T cells (Tregs)

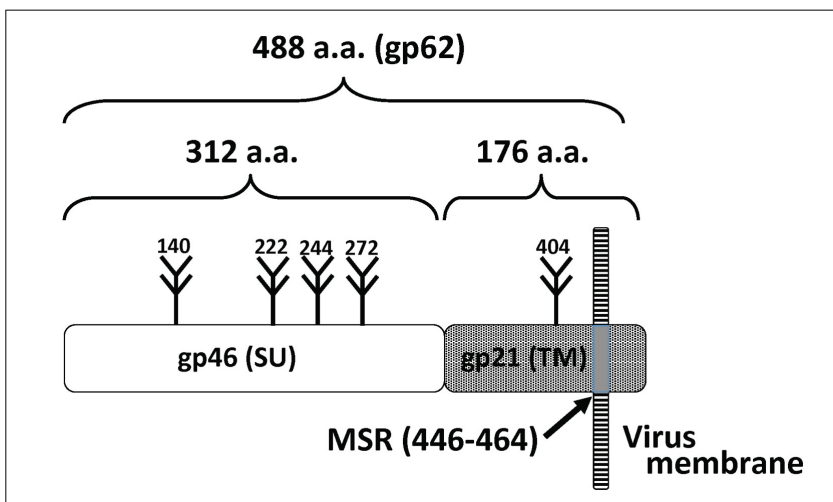

FIGURE 2 | Organization of Env proteins. The surface unit (SU) gp46 and transmembrane unit (TM) gp21 and are shown. Five potential $\mathrm{N}$-glycosylation sites and the membrane-spanning region (MSR) are shown. 
might also be infected in some patients (Chen et al., 2006; Yano et al., 2007; Abe et al., 2008; Toulza et al., 2009).

Human $\mathrm{T}$ cell leukemia virus type 1 - associated myelopathy and tropical spastic paraparesis primarily affects the thoracic spinal cord, and patients often show limb paraparesis (Osame et al., 1986; Osame and Igata, 1989). In the brains of some HAM/TSP patients, astrocytes are productively infected with HTLV-1. Several lines of evidence, such as IgG deposits in CNS parenchyma, indicate that the blood-brain barrier (BBB) is disrupted in HAM/TSP patients (Walter et al., 1994; Lehky et al., 1995). In addition, the infection of adherent cells in vivo has been reported: sweat gland epithelia, salivary glands, vascular endothelial cells, and mammary glands (Setoyama et al., 1998).

In infected individuals, HTLV-1 is primarily found in CD4+ $\mathrm{T}$ cells, while HTLV-2 has frequently been found in CD8+ T cells (Richardson et al., 1990; Ijichi et al., 1992). Although CD4+ T cells are the major reservoir, other hematopoietic cells $[\mathrm{CD} 8+\mathrm{T}$ cells, B lymphocytes, monocytes, macrophages, dendritic cells (DCs), and megakaryocytes], synovial cells, and glial cells (astrocytes and microglial cells) have been infected with HTLV-1 (Kitajima et al., 1991; Koyanagi et al., 1993; Walter et al., 1994; Lehky et al., 1995; Hanon et al., 2000a; Nagai et al., 2001). It is intriguing that HTLV-I-specific, but not Epstein-Barr virus-specific, CD8+ T lymphocytes were shown to be preferentially infected with HTLV1 (Wucherpfennig et al., 1992; Goon et al., 2002). The ratio of HTLV-1 genome-positive cells in some HAM/TSP patients was reported to be as high as 40-65\% in the CD4+ and CD8+ subset. The proportion of cells expressing HTLV- 1 RNA is $0.02-0.1 \%$ in both subsets. Other reports also show the expression of the HTLV1 genome in vivo (Cho et al., 1995; Hanon et al., 2000b), although HTLV-1 RNA expression in vivo is known to be highly suppressed in HTLV- 1 carriers and ATL patients.

Experiments using deuterated glucose labeling to quantify in vivo lymphocyte dynamics in $\mathrm{HTLV}-1$-infected individuals revealed that $\mathrm{CD} 4+/ \mathrm{CD} 45 \mathrm{RO}+$ and $\mathrm{CD} 8+/ \mathrm{CD} 45 \mathrm{RO}+\mathrm{T}$ lymphocyte proliferation was elevated in HTLV-1-infected subjects; about $10^{12}$ more lymphocytes were estimated to be produced per year in HTLV-1-infected subjects compared with HTLV-Iuninfected subjects (Asquith et al., 2007). This high cell turnover was correlated with Tax expression measured ex vivo. These findings suggest that HTLV-1 genes may be expressed somewhere in vivo. These virological, pathological, and clinical features of HTLV-1 infection can or will be explained by the cell tropism and pathogenicity of HTLV-1.

\section{ANIMAL MODELS OF HTLV-1 INFECTION}

Animal models of HTLV-1 infection and transmission have clarified the effects of neutralizing antibodies and viral and host factors on persistent HTLV-1 infections. Some non-human primates, rabbits, rats, and mice, can be infected with HTLV-1 (Lairmore et al., 2005). In these models, HTLV-1 is also detected in various types of hematopoietic cells and non-hematopoietic tissues, including the brain, lung, kidney, heart, liver, and thyroid.

Milk transmission of HTLV-1 in rabbits can be inhibited through passive immunizations using neutralizing antibodies or HTLV-1 Env vaccines (Akagi et al., 1985; Nakamura et al., 1987; Uemura et al., 1987; Kataoka et al., 1990; Sawada et al., 1991).
Although there is a strong immune response to HTLV proteins, such Env or Tax, through the humoral or cellular immune system in humans, HTLV-1 can sustain life-long persistence in subjects and HTLV-1-infected lymphocytes can robustly proliferate as described above.

The HTLV-1 accessory proteins, p12/p8, p30, and p13, have been implicated in the transmission and spread of HTLV-1 in vivo or in HTLV-1 persistence in animal models, although these proteins were shown to have little effect on HTLV-1 infection in vitro (Albrecht et al., 2000; Silverman et al., 2004; Nicot et al., 2005; Lairmore et al., 2011). The viral protein p12 localizes in the endoplasmic reticulum (ER), binds major histocompatibility complex (MHC) class I in the ER, decreases surface expression of MHC-I, ICAM-1, and intercellular adhesion molecule-2 (ICAM2 ), and inhibits the killing of HTLV-1-infected cells by natural killer cells. p8, Proteolytically cleaved from $\mathrm{p} 12$, increases $\mathrm{T}$ cell contact through LFA-1 clustering and augments the number and length of cellular conduits among $\mathrm{T}$ cells. $\mathrm{p} 8$ or even virions are transferred to neighboring $\mathrm{T}$ cells through these conduits (van Prooyen et al., 2010). The p30 protein will localize in the nucleus and retain the Tax/Rex messenger inside the nucleus and enhances cell survival by altering cell cycle regulation. p13 Localizes in the nucleus and mitochondria. p13 can modulate cell survival and have an pivotal role in early virus transmission and virus persistence in vivo.

\section{INFECTION OF CELLS WITH HTLV-1 IN VITRO}

Unlike most other viruses, cell-free HTLV-1 is poorly infectious, and efficient infection requires cell-to-cell contact (Clapham et al., 1983; Hoshino et al., 1983; Nagy et al., 1983; Fan et al., 1992; Mazurov et al., 2010). HTLV-1-infected cells produce small amounts and low titers of the virus. However, HTLV-1 has passed on from generation to generation among humans for a long time.

Adherent cells persistently infected with HTLV-1 have rarely been isolated (Hoshino et al., 1983; Ho et al., 1984; Hoxie et al., 1984; Yoshikura et al., 1984; Fan et al., 1992; Mazurov et al., 2010). However, the HTLV receptor has been detected in almost all vertebrate cells (Sutton and Littman, 1996; Trejo and Ratner, 2000; Manel et al., 2005a) in contrast to the limited cell tropism in vivo. Some cell lines will form numerous syncytia upon co-cultivation with HTLV-1-producing cells, while others are resistant to syncytia formation (Jassal et al., 2001).

Surface unit-Fc fusion proteins consisting of the Fc portion of immunoglobulin and HTLV-1 SU [either full-length gp46 or the $\mathrm{N}$-terminal Receptor-Binding Domain (RBD) of SU; Figure 3] have been used to detect and analyze HTLV-1 receptors. The SUFc binds to almost all vertebrate cell lines and can often bind to cell lines considered to be negative for the receptor due to their resistance to Env-mediated syncytia formation (Sutton and Littman, 1996; Trejo and Ratner, 2000; Jassal et al., 2001; Manel et al., 2005a). The use of SU-Fc has, however, clarified that HTLV-1 receptors are lacking on the surface of resting or naive $\mathrm{CD} 4+$ and CD8 + T cells but HTLV-1 receptors can be rapidly upregulated by treating them with PHA/IL-2, TGF- $\beta$, or interleukin-7 (Moriuchi and Moriuchi, 2002; Manel et al., 2003a; Nath et al., 2003; Jones et al., 2005a). These properties have been used to characterize an HTLV-1 receptor candidate as described below. 


\section{VIRAL SYNAPSE AND BIOFILM-LIKE STRUCTURE IN HTLV-1 INFECTION}

Special structures permitting efficient transmission of HTLV-1 have been identified. Namely, viral or virological synapses (VS), similar to immune or immunological synapses, can be made after cell-to-cell contacts between HTLV-1-infected and uninfected T cells (Igakura et al., 2003; Jenkins et al., 2009). Lymphocyte contact will rapidly induce polarization of the cytoskeleton, especially the microtubule-organizing center (MTOC), of HTLV-1-infected cells at the cell-cell junction: HTLV-I genome and Gag proteins accumulate at the junction. Subsequently, polarization is promoted by Tax, and the formation of VS leads to the entry of viral particles, viral proteins, and genomic RNA into uninfected target cells (Igakura et al., 2003; Nejmeddine et al., 2005; Jenkins et al., 2009). VS also lead to the efficient transmission of human immunodeficiency virus type 1 (HIV-1): its transmission takes place even in the presence of neutralizing antibodies. The viral envelope protein is required for the transmission of HTLV-1, suggesting that complete HTLV-1 virions are transferred across the synapse (Nejmeddine et al., 2009). Electron tomography combined with the immunostaining of viral proteins has demonstrated the presence of enveloped HTLV-1 particles in the VS formed between naturally infected lymphocytes and uninfected cells (Majorovits et al., 2008).

More recently it was shown that HTLV-1 virions are stored outside the cells within a protective microenvironment: specific components of the extracellular matrix, including collagen, galectin-3, and tetherin, form a biofilm-like structure on the outer surface of infected cells (Pais-Correia et al., 2009). Following contact with T cells, these structures are rapidly transferred from infected lymphocytes to uninfected cells, resulting in the infection of target cells. HTLV-1 $\mathrm{p} 8$ promotes the formation of cellular conduits between T cells as described above (van Prooyen et al., 2010). These three structures will promote highly efficient transmission of the virus from cells to cells in vivo, as compared to the transmission of cell-free virus produced by infected cells to uninfected cells.

\section{INFECTION OF DENDRITIC CELLS}

Dendritic cells can also be infected with HTLV-1 (Macatonia et al., 1992). Recently, it was demonstrated that DCs could play a central role in HTLV-1 infection in vivo. DCs participate in the cell-tocell transmission of HTLV-1 in two ways: (1) DCs can capture and transfer HTLV-1 virions to fresh T cells and (2) infected DCs can transmit newly made virions to fresh $\mathrm{T}$ cells (Macatonia et al., 1992; Knight et al., 1993; Ceccaldi et al., 2006). Monocytederived DCs form syncytia and can be infected with HTLV-1 upon co-culture with HTLV-1-producing lymphocytes. Monoclonal antibodies (MAbs) against DC-specific ICAM-3-grabbing non-integrin (DC-SIGN) can inhibit the formation of HTLV-1induced syncytia. HTLV-1, however, does not bind directly to DC-SIGN, and the enhanced syncytium formation is mediated through the interaction of DC-SIGN with ICAM-2 and ICAM-3.

More recently, DCs have been shown to be readily infected through cell-free HTLV-1 (Jones et al., 2008). Cell-free HTLV-1 can efficiently infect myeloid and plasmacytoid DCs (pDC). DCs exposed to HTLV-1 efficiently transfer virus to autologous primary CD4+ T cells. This DC-mediated transfer of HTLV-1 involves heparan sulfate proteoglycans (HSPGs), neuropilin-1 (NRP-1), and DC-SIGN (Jain et al., 2009). Thus, DCs can facilitate HTLV1 transmission, dissemination, and persistence through different mechanisms in vivo.

\section{OTHER CELLULAR FACTORS AFFECTING HTLV-1 INFECTION IN VITRO}

Many cellular factors that affect HTLV-1-induced syncytium formation have been identified. HTLV-1 Tax affects the expression of numerous molecules, such as vascular cell adhesion molecule 1 (VCAM-1) or ICAM-1 (Tanaka et al., 1995; Hildreth et al., 1997; Daenke et al., 1999). VCAM-1 promotes HTLV-1-induced syncytia formation. ICAM-1, ICAM-3, or VCAM-1 is required for syncytia formation in K562 induced by HTLV-1-producing MT-2 cells. Antibodies against $\beta$-integrins can inhibit this syncytium formation (Daenke et al., 1999). MAbs that inhibit HTLV-1-induced syncytium formation were produced in mice and shown to recognize class II MHC molecules (Hildreth, 1998). The heat shock cognate protein 70 (HSC70) directly binds to gp46. The transduction of human HSC70 cDNA into mouse cells, however, did not support HTLV-I entry: HSC70 markedly promoted syncytium formation upon co-cultivation with HTLV-I-producing cells but did not facilitate HTLV-I entry (Fang et al., 1999). Tetraspanin (CD82) was also shown to bind HTLV-1 Env proteins (Pique et al., 2000; Mazurov et al., 2006). Thus, HTLV-1-induced syncytium formation is affected by HSC70, CD82, ICAM-1, ICAM-3, LFA-1, VCAM-1, integrin $\beta 2$, integrin $\beta 7$, or Dlg protein (Blot et al., 2004). These factors might also affect the spread and pathogenicity of HTLV-1 in vivo.

Plasma membrane microdomains rich in cholesterol are important for the entry of many viruses, including retroviruses. The depletion of cholesterol using cyclodextrin inhibits the entry of HTLV-1 and HTLV-I pseudotypes, whereas it did not affect the receptor-binding activity of HTLV-1. Using SU-Fc, the HTLV-I receptor was shown to co-localize with a raft-associated marker. Some MAbs that inhibited HTLV-1-induced syncytium formation recognized proteins in lipid rafts. The results of these studies suggest that lipid rafts might play a role in HTLV-1-induced syncytium formation and that cholesterol is required in a post-binding step (Wielgosz et al., 2005). Intact lipid rafts are also necessary for the formation of the VS as described above (Igakura et al., 2003; Jolly and Sattentau, 2005).

\section{ENHANCEMENT OF HTLV-1 INFECTION BY HSPG}

The HSPG family is composed of core proteins, such as syndecans or glypicans, associated with one or more of the sulfated polysaccharide side chains heparan sulfate (HS) glycosaminoglycans. HSPGs have been shown to bind to many viruses, such as herpes simplex viruses, flaviviruses, picornaviruses, and HIV1 (Ibrahim et al., 1999; Shukla et al., 1999) and promote their receptor-mediated entry.

The presence of HSPGs on the cell surface has been shown to affect HTLV-1 binding and viral entry (Okuma et al., 2003; Pinon et al., 2003a). Osteoprotegerin (OPG) inhibited the HTLV-1 infection of cell lines, indicating that this inhibition is due to the binding of OPG to cellular HS (Okuma et al., 2003). HTLV-1 SU-Fc binds to HSPGs on mammalian cells, and the enzymatic removal of 
HSPGs from HeLa and CHOK1 cells also reduced SU-Fc binding and plating of the HTLV-1 pseudotype (Pinon et al., 2003a). As compared with SU-Fc binding in HSPG-positive CHOK1 hamster cells, the plating efficiency of HTLV-1 in a CHOK1 subline completely lacking HSPG was markedly reduced but apparently detectable. Thus, HSPGs might not be absolutely required for HTLV-1 entry.

More recently, HSPGs were also found to promote the HTLV-1 infection of primary CD4+ T cells and DCs (Jones et al., 2005b, 2006). Resting CD4+ T cells are negative for detectable levels of HSPGs and HTLV-1 receptor(s). HSPGs are expressed following immune activation, and the cells become susceptible to HTLV-1 (Nath et al., 2003; Jones et al., 2005a). The enzymatic removal of HSPGs on the surface of primary CD4+ $\mathrm{T}$ cells also reduced the binding of HTLV-1 SU and HTLV-1 virions. HTLV-1 is more dependent on HSPGs than HTLV-2 (Jones et al., 2006). Using HTLV-1/HTLV-2 recombinants, it was shown that HTLV-1 binding to HSPGs requires the C-terminal domain (CTD) of HTLV-1 SU (amino acids 215-313; Figure 3). Thus, HSPGs play an important role in the binding and entry of HTLV-1 into primary CD4+ $\mathrm{T}$ cells. Recently, we observed that the susceptibilities of established cell lines to HTLV-1 are well correlated with the number of HS chains, especially heparin-like regions, on the cell surface and are inversely correlated with the length of the HS chains (Tanaka et al., 2012).

\section{EFFECTS OF GLUT1 ON HTLV-1 INFECTION}

The observation that the transduction of HTLV-1 SU into cells delays medium acidification led to an investigation of glucose transporter 1 (GLUT1) as a candidate HTLV-1 receptor. Subsequently, GLUT1 was found to bind to HTLV-1 SU and promote HTLV-1 entry into adherent cell lines (Manel et al., 2003b). GLUT1 is a 12-membrane-spanning receptor for glucose transport across the cell membrane. GLUT1 is expressed in all of mammalian cell lines that have been tested. The transduction of GLUT1 increases the susceptibility of markedly HTLV-1-resistant cell lines, such as MDBK, to HTLV-1 Env-mediated cell fusion and infection (Coskun and Sutton, 2005). Antibodies against GLUT1, especially against extracellular loop 1 (ECL1), inhibit syncytia formation, and the infection of primary CD4+ T lymphocytes (Manel et al., 2005b; Jin et al., 2006a). Similar to HSPGs, GLUT1 is not detected in resting lymphocytes. The treatment of resting $\mathrm{T}$ lymphocytes with TGF- $\beta$ or IL-7 rapidly induces GLUT1 expression on the cell surface (Jones et al., 2005a).

Quantitative analyses have shown that CD4+ T cells, which are the primary target of HTLV-1, express higher levels of HSPGs than CD8+ T cells. In contrast, CD8+ T cells, which are the primary targets of HTLV-2, express GLUT1 at much higher levels than $\mathrm{CD} 4+\mathrm{T}$ cells. These studies suggest that the difference in the in vitro cellular tropism between HTLV-1 and HTLV-2 (Jones et al., 2006) and the in vivo tropisms of these viruses can be explained through different interactions between HTLV-1 and HTLV-2 Env proteins and $\mathrm{CD} 4+$ or $\mathrm{CD} 8+\mathrm{T}$ cells.

The glioblastoma U87 cell line expresses low levels of GLUT1 due to a deletion in the GLUT1 gene but is easily infected by the HTLV-1 pseudotype (Jin et al., 2006b). Among U87 cell clones, the levels of cell surface GLUT1, however, correlate well with the plating efficiency of HTLV-1 pseudotype viruses, but not their interactions with SU-Fc. These findings together with other observations suggest that molecules other than GLUT1 are also involved in HTLV-1 entry steps, i.e., attachment and binding, and GLUT1 affects the post-binding or fusion step of HTLV-1 infection.

\section{EFFECTS OF NEUROPILIN-1 ON HTLV-1 INFECTION}

In 2006, neuropilin-1 (NRP-1) was reported to display the expected properties of a HTLV-1 receptor. NRP-1 is a $130-\mathrm{kDa}$ single membrane-spanning glycoprotein, primarily modified by heparan sulfate (HS), or chondroitin sulfate (Soker et al., 1998; Shintani et al., 2006). NRP-1 is highly conserved among vertebrate species. NRP-1 is a receptor for the chemo-repellent semaphorin III (Sema III), which is a secreted protein known to be necessary for neuronal growth and development. NRP-1 can also bind to VEGF165. VEGF is a polypeptide growth factor with five alternatively spliced isoforms; VEGF165 is the most abundant isoform. NPR-1 is one of the immune synapse factors that is primarily expressed in T cells; its expression is not detectable in resting $\mathrm{T}$ cells but is rapidly upregulated after activation (Romeo et al., 2002; Tordjman et al., 2002). pDC and endothelial cells also express NRP-1. Although the in vivo expression of NRP-1 is relatively limited, NRP-1 is expressed in many tumor cells and in almost all established cell lines (Soker et al., 1998).

Human $\mathrm{T}$ cell leukemia virus type $1 \mathrm{SU}$ inhibits $\mathrm{T}$ cell proliferation in a mixed lymphocyte reaction, while anti-NRP-1 antibodies also inhibit T cell proliferation (Ghez et al., 2006). The possibility of the involvement of NRP-1 in HTLV entry has also been examined (Shintani et al., 2006). NRP-1 over expression increases HTLV-1 Env-mediated syncytium formation and promotes HTLV-1 and HTLV-2 infection, whereas the downregulation of endogenous NRP-1 inhibits HTLV infection (Ghez et al., 2006). Therefore, NRP-1 expression levels in vivo and in vitro might explain HTLV-1 infection and tropism.

VEGF165 and HTLV-1 SU competitively and HS-dependently bind to NRP-1. The KPXR motif is critical for the direct binding of VEGF165 to NRP-1 and this motif is also found in HTLV$1 \mathrm{SU}$. The pentapeptide sequence of SU corresponding to this motif (a.a. 90-94, KKPNR) is highly conserved among HTLV1 strains, and this peptide blocks HTLV-1 entry into primary T cells or DCs (Lambert et al., 2009). These findings indicate that NRP-1 plays a pivotal role in HTLV-1 binding. Because NRP-1 is modified by HS (Shintani et al., 2006), HTLV-1 SU might interact directly with HS conjugated to NRP-1. Thus, HTLV-1 SU will bind to NRP-1 in two ways: an HSPG-mediated indirect interaction and a KKPNR sequence-mediated direct interaction. This motif is also the target of neutralizing antibodies (Palker et al., 1992; Figure 3).

Important roles for NPR-1 and HSPG in HTLV-1 infection of DCs and CD4+ T cells have also been shown (Ghez et al., 2006; Jones et al., 2009; Lambert et al., 2009). GLUT1 and NRP-1 are concentrated in viral synapses (Romeo et al., 2002). In contrast, the effects of VEGF165 and anti-GLUT1 on the infection of U87 cells, primary astrocytes or HeLa cells appear to be more complicated (Jin et al., 2006b, 2010). 


\section{A RECEPTOR COMPLEX MODEL OF HTLV-1 ENTRY}

Recent studies have revealed that HTLV-1 infection in vitro involves interactions with three different molecules, HSPG, NRP1, and GLUT1. HTLV-1 SU can bind to NRP-1 in two ways: an HSPG-mediated indirect interaction and/or a KKPNR sequencemediated direct interaction as described above. NRP-1 and GLUT1 can also form a complex in the presence of HTLV-1 Env (Ghez et al., 2006; Jones et al., 2009; Lambert et al., 2009). NRP-1 and GLUT1 as well as HS and NRP-1 will work together to promote HTLV-1 entry. The level of GLUT1 expression on target cells correlates well with the titer of HTLV-1 pseudotypes, but not with the level of HTLV-1 binding (Delamarre et al., 1994; Manel et al., 2005b; Jones et al., 2009), indicating a role for GLUT1 in the fusion step that follows the initial binding.

The findings described above lead to a multi-receptor model for HTLV-1 entry (Ghez et al., 2010; Jones et al., 2011). Namely, during the initial binding phase, the CTD of HTLV-1 SU interacts with HSPGs. This interaction would enhance the probability and stability of the HTLV-1 SU interaction with NRP-1. This binding to NRP-1 triggers a conformational change to expose the GLUT1binding domain. Finally, the interaction of SU with GLUT1 triggers the translocation of TM gp21. In this model, NRP-1 is the primary binding receptor, while GLUT1 is the fusion receptor.

\section{ROLES OF SU PROTEIN gp46 IN HTLV-1 INFECTION}

The HTLV-1 env gene encodes a 488 amino acid precursor protein, and a $62-\mathrm{kDa}$ protein (gp62) is produced after the addition of five N-glycan chains, four in SU, and one in TM. gp62 is cleaved into the SU gp46 and TM gp21 subunits (Figures 2-4). SU-TM complexes are organized as trimers and transported to the surface of infected cells (Delamarre et al., 1996). Site-directed mutagenesis demonstrates that the glycosylation of each site is required for syncytium formation (Pique et al., 1992).

Human T cell leukemia virus type 1 gp46 SU can be organized into four structural domains (Figure 3): a signal peptide (residues 1-25), an N-terminal region (26-180), a proline-rich region (PRR; 181-215), and a CTD (216-312). The first 155 amino acid residues after the signal peptide are identified as the RBD (Delamarre et al., 1994; Kim et al., 2004). This organization of SU is similar to other retroviruses (Lavillette et al., 1998). The binding of RBD to viral receptors transmits a PRR-controlled signal to CTD, and this interaction leads to the activation of the fusion function of gp21 TM. The PRR domain is shown to be a hinge region that is subject to the conformational changes induced by receptor-binding.

The functional domains of the HTLV-1 Env have also been identified through analyses of the effects of neutralizing antibodies and specific mutations in Env on HTLV-1 infectivity (Kuroki et al., 1992; Palker et al., 1992; Baba et al., 1993; Desgranges et al., 1994; Tanaka et al., 1994; Londos-Gagliardi et al., 1996). The residues between 100 and 200 amino acids of the SU have been shown to be the targets of neutralizing antibodies. The mutations introduced in these regions reduce the ability of HTLV-1 Env to induce syncytium formation and virus infection. Antibodies in $78 \%$ of sera of HTLV-I seropositive subjects reacted with a synthetic peptide corresponding to amino acids 190-209 (LondosGagliardi et al., 1996). A synthetic peptide, P-197, consisting of

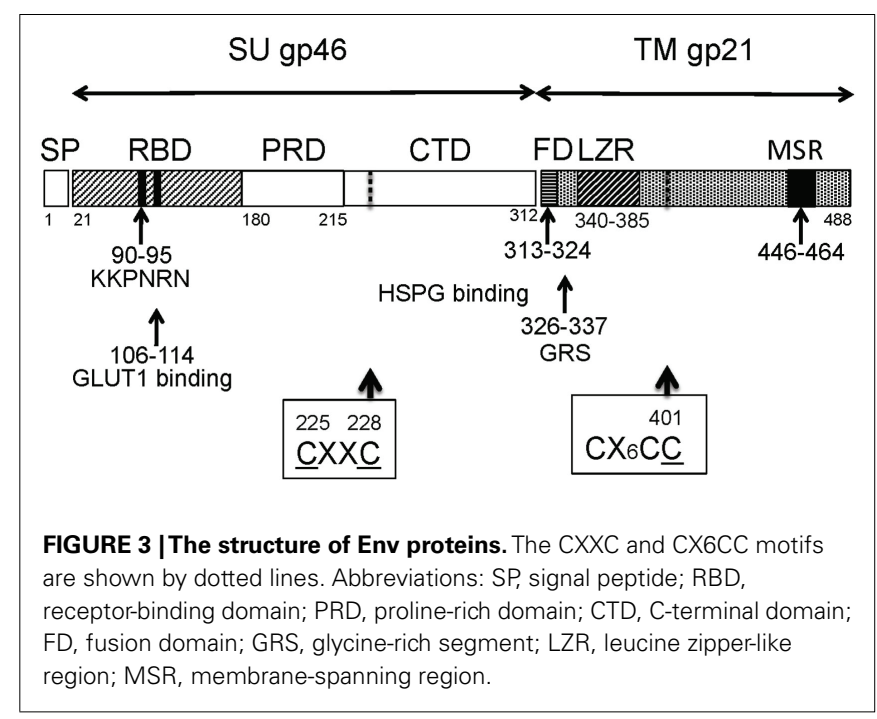

amino acids 197-216 also strongly inhibits HTLV-1-induced cell fusion of various cells, such as Molt-4 and HeLa (Brighty and Jassal, 2001). The rat monoclonal antibody LAT-27 recognizes a peptide epitope (amino acids 191-196) and potently neutralizes cell-free HTLV-1 infection and inhibits HTLV-1-induced syncytia formation (Tanaka et al., 1991). Antibodies binding to the PRR domain will prevent SU structural rearrangements leading to membrane fusion, rather than blocking interactions between SU and the cellular receptors. Some neutralizing antibodies may recognize secondary or tertiary structures of HTLV-1 Env proteins, and so the regions recognized by these antibodies are not necessarily located in the functional domains for HTLV-1 entry.

Furthermore, the adsorption of the neutralizing activities using a set of shorter peptides has shown that the six residues (KKPNRN; position 90-95) comprise the minimal neutralizing epitope, while residues 86-107 are involved in interactions with NRP-1 and GLUT1 (Figure 3). Specifically, a pentapeptide (residues 90-94) blocks the binding of HTLV-1 to cells and NRP-1 (Lambert et al., 2009). Similarly, site-directed mutagenesis experiments showed that D106 and Y114 of SU are important for GLUT1-binding (Manel et al., 2003b). These studies have suggested regions important for the interaction of HTLV-1 SU with the cellular factors (Figure 3).

\section{ROLES OF TM PROTEIN gp21 IN HTLV-1 INFECTION}

Retrovirus entry into cells occurs through the fusion of the viral envelope either with the cell membrane or with the endosomal membrane after internalization through an endocytic pathway (Mothes et al., 2000; Marsh and Helenius, 2006). The entry process starts by a binding step mediated by SU as described above and a subsequent TM-mediated fusion step. During virus production, TM is maintained in an inactive conformation through an association with SU, and the fusion domain (FD) in TM is not exposed. This conformation prevents premature Env activation that will lead to virus inactivation. The hydrophobic FD is located at its N-terminal region (Figure 3). The dissociation of TM from the SU-TM complex results in the projection of FD into the cell membrane. This dissociation involves the formation of a six-helix 
coiled-coil bundle that induces membrane fusion (Maerz et al., 2000; Marsh and Helenius, 2006; Mirsaliotis et al., 2007; Lamb et al., 2009).

Four domains conserved in retroviral TM glycoproteins are also present in HTLV-1 TM (Kobe et al., 1999): (1) an aminoterminal hydrophobic domain with characteristics of a FD (Kim et al., 2000); (2) a leucine zipper-like region (LZR) with an amphipathic $\alpha$-helical structure capable of self-association as a coiledcoil (Maerz et al., 2000; Pinon et al., 2003b; Mirsaliotis et al., 2007; Lamb et al., 2009); (3) a domain containing the conserved motif, which forms an intramolecular disulfide link; and (4) a FD linked to the coiled-coil core through a conserved sequence rich in glycine [glycine-rich segment (GRS), M(326) to S(337); Wilson et al., 2005; Figure 3].

Synthetic peptides based on the leash and $\alpha$-helical region (LHR) of gp21 are potent inhibitors of virus entry into cells. Inhibitory peptides target the triple-stranded coiled-coil motif of the fusion-active gp21 and block its conformational change (Mirsaliotis et al., 2008): These peptides are expected to function in a similar way to clinically available enfuvirtide (T-20) type inhibitors of HIV-1.

\section{ISOMERIZATION IN HTLV-1 Env PROTEINS}

The SU and TM subunits are associated through an inter-subunit disulfide link. Receptor-binding or low $\mathrm{pH}$ in the endosome decreases this association, leading to dissociation of the SU subunit from the virus and translocation of the TM subunit for membrane fusion (Pinter et al., 1997; Barnard et al., 2004; Wallin et al., 2004; Li et al., 2008). In the case of murine leukemia virus (MuLV) Env, the inter-subunit disulfide has been shown to link the CXXC motif in $\mathrm{SU}$ to the conserved $\mathrm{CX}_{6} \mathrm{CC}$ motif in the TM, and these motifs are also conserved in deltaretroviruses, such as HTLV-1. The intersubunit disulfide is then rearranged into a disulfide isomer within the motif (Figures 3 and $\mathbf{4}$ ).

Human T cell leukemia virus type 1 Env proteins contain the disulfide isomerization motifs $\mathrm{C}$ (225) XXC(228; e.g., CIVC in gp46 $\mathrm{SU})$ and $\mathrm{CX}_{6} \mathrm{CC}(401$; e.g., CKALQERCC in gp21 TM; Figures 3 and 4). Thus, it has been proposed that $\mathrm{C}(228)$ is linked to $\mathrm{C}(401$; Li et al., 2008). This disulfide link will be rearranged through isomerization into the intra-subunit disulfide link between C(225) and $\mathrm{C}(228)$. This rearrangement results in $\mathrm{SU}$ dissociation and TM translocation for membrane fusion. Thus, similar to MuLV Env, the membrane fusion of HTLV-1 Env was shown to occur under neutral conditions at the cell surface (Li et al., 2008; Figure 4). A set of these motifs is lacking in Rous sarcoma virus or HIV-1 but BLV (Barnard et al., 2004; Li et al., 2008).

Murine leukemia virus Env shows low spontaneous intersubunit disulfide isomerization activity (Li et al., 2008), and MuLV and BLV are relatively stable in culture medium (Shinagawa et al., 2012). In contrast, cell-free HTLV-1 shows a low infectivity. The low infectivity might be related to a high spontaneous intersubunit disulfide isomerization activity. We observed that the

\section{REFERENCES}

Abe, M., Uchihashi, K., Kazuto, T., Osaka, A., Yanagihara, K., Tsukasaki,

K., Hasegawa, H., Yamada, Y., and
Kamihira, S. (2008). Foxp3 expression on normal and leukemic CD4+CD25+ T cells implicated in human T-cell leukemia virus type-1

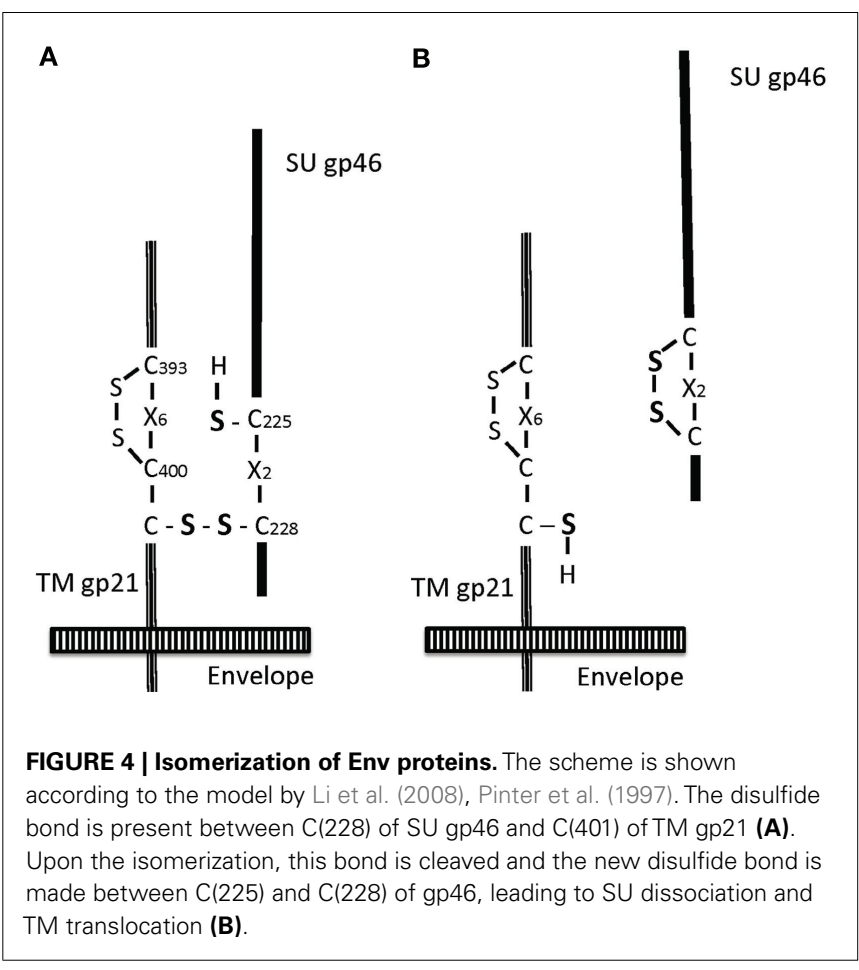

spontaneous dissociation of SU from SU-TM complexes in HTLV1 virions occurs readily over a wide range of temperatures: the half-life of HTLV- 1 infectivity at various temperatures $\left(0-37^{\circ} \mathrm{C}\right)$ is as short as 30-60 $\mathrm{min}$ (Shinagawa et al., 2012). Derse et al. (2001) have, however, reported that the half-life of HTLV-1 is about $3.5 \mathrm{~h}$ at $37^{\circ} \mathrm{C}$ : in their system, HTLV-1 pseudotype was used and its infectivity was measured by luciferase assays. We have assumed that the isomerization of HTLV-1 Env will occur spontaneously and rapidly in culture medium and HTLV-1 will easily lose the infectivity. HTLV-1 can afford to have this property since most HTLV-1 infections in vivo occur from cell-to-cell.

\section{CONCLUSION}

Cellular factors important for HTLV-1 infection and persistence in vivo and in vitro have been investigated for 30 years. Recently, three factors have been found to play crucial roles in HTLV-1 entry: HSPGs, glucose transporter GLUT1, and neuropilin-1 (NRP-1). These molecules have been shown to form complexes with HTLV$1 \mathrm{SU}$ to promote HTLV-1 entry into primary cells and established cell lines. The functional domains of the HLTV-1 Env proteins and their interactions with these molecules have been elucidated. However, mutant cells lacking an enzyme synthesizing HS, xylosyl transferase, or mutant cells expressing little GLUT1 are apparently susceptible to HTLV-1. It has not been proven whether cells that are completely resistant to HTLV-1 will become susceptible to HTLV-1 when all or a combination of these three molecules are transduced into the cells.

is inconsistent with Treg cells. Eur. J. Haematol. 81, 209-217.

Akagi, T., Takeda, I., Oka, T., Ohtsuki, Y., Yano, S., and Miyoshi, I.
(1985). Experimental infection of rabbits with human T-cell leukemia virus type 1. Jpn. J. Cancer Res. 76, 86-94. 
Albrecht, B., Collins, N. D., Burniston, M. T., Nisbet, J. W., Ratner, L., Green, P. L., and Lairmore, M. D. (2000). Human T-lymphotropic virus type 1 open reading frame I p12(I) is required for efficient viral infectivity in primary lymphocytes. J. Virol. 74, 9828-9835.

Araujo, A., and Hall, W. W. (2004). Human T-lymphotropic virus type II and neurological disease. Ann. Neurol. 56, 10-19.

Arnold, J., Yamamoto, B., Li, M., Phipps, A. J., Younis, I., Lairmore, M. D., and Green, P. L. (2006). Enhancement of infectivity and persistence in vivo by $\mathrm{HBZ}$, a natural antisense coded protein of HTLV-1. Blood 107, 3976-3982.

Asquith, B., Zhang, Y., Mosley, A. J., de Lara, C. M., Wallace, D. L., Worth, A., Kaftantzi, L., Meekings, K., Griffin, G. E., Tanaka, Y., Tough, D. F., Beverley, P. C., Taylor, G. P., Macallan, D. C., and Bangham, C. R. (2007). In vivo $\mathrm{T}$ lymphocyte dynamics in humans and the impact of human $\mathrm{T}$ lymphotropic virus 1 infection. Proc. Natl. Acad. Sci. U.S.A. 104, 8035-8040.

Baba, E., Nakamura, M., Tanaka, Y., Kuroki, M., Itoyama, Y., Nakano, S., and Niho, Y. (1993). Multiple neutralizing B-cell epitopes of human T-cell leukemia virus type 1 (HTLV1) identified by human monoclonal antibodies. A basis for the design of an HTLV-1 peptide vaccine. $J$. Immunol. 151, 1013-1024.

Barnard, R. J., Narayan, S., Dornadula, G., Miller, M. D., and Young, J. A. (2004). Low $\mathrm{pH}$ is required for avian sarcoma and leukosis virus Envdependent viral penetration into the cytosol and not for viral uncoating. J. Virol. 78, 10433-10441.

Blattner, W. A., Kalyanaraman, V. S., Robert, G. M., Lister, T. A., Galton, D. A., Sarin, P. S., Crawford, M. H., Catovsky, D., Greaves, M., and Gallo, R. C. (1982). The human type-C retrovirus, HTLV, in Blacks from the Caribbean region, and relationship to adult T-cell leukemia/lymphoma. Int. J. Cancer 30, 257-264.

Blot, V., Delamarre, L., Perugi, F., Pham, D., Benichou, S., Benarous, R., Hanada, T., Chishti, A. H., Dokhelar, M. C., and Pique, C. (2004). Human Dlg protein binds to the envelope glycoproteins of human Tcell leukemia virus type 1 and regulates envelope mediated cell-cell fusion in T lymphocytes. J. Cell Sci. 117, 3983-3993.

Brighty, D. W., and Jassal, S. R. (2001). The synthetic peptide P-197 inhibits human T-cell leukemia virus type
1 envelope-mediated syncytium formation by a mechanism that is independent of Hsc70. J. Virol. 75, 10472-10478.

Cann, A. J., Rosenblatt, J. D., Wachsman, W., Shah, N. P., and Chen, I. S. Y. (1985). Identification of the gene responsible for human T-cell leukemia virus transcriptional regulation. Nature 318, 571-574.

Ceccaldi, P. E., Delebecque, F., Prevost, M. C., Moris, A., Abastado, J. P., Gessain, A., Schwartz, O., and Ozden, S. (2006). DC-SIGN facilitates fusion of dendritic cells with human T-cell leukemia virus type 1-infected cells. J. Virol. 80, 4771-4780.

Chen, S., Ishii, N., Ine, S., Ikeda, S., Fujimura, T., Ndhlovu, L. C., Soroosh, P., Tada, K., Harigae, H., Kameoka, J., Kasai, N., Sasaki, T., and Sugamura, K. (2006). Regulatory T cell-like activity of Foxp3+ adult $\mathrm{T}$ cell leukemia cells. Int. Immunol. 18, 269-277.

Cho, I., Sugimoto, M., Mita, S., Tokunaga, M., Imamura, F., and Ando, M. (1995). In vivo proviral burden and viral RNA expression in T cell subsets of patients with human $\mathrm{T}$ lymphotropic virus type-1-associated myelopathy/tropical spastic paraparesis. Am. J. Trop. Med. Hyg. 53, 412-418.

Clapham, P., Nagy, K., Cheingsong, P. R., Exley, M., and Weiss, R. A. (1983). Productive infection and $\mathrm{c}$ ellfree transmission of human T-cell leukemia virus in a nonlymphoid cell line. Science 222, 1125-1127.

Coskun, A. K., and Sutton, R. E. (2005). Expression of glucose transporter 1 confers susceptibility to human T-cell leukemia virus envelopemediated fusion. J. Virol. 79, 4150-4158.

Daenke, S., McCracken, S. A., and Booth, S. (1999). Human T-cell leukaemia/lymphoma virus type 1 syncytium formation is regulated in a cell-specific manner by ICAM-1, ICAM- 3 and VCAM- 1 and can be inhibited by antibodies to integrin beta2 or beta7. J. Gen. Virol. 80, 1429-1436.

Delamarre, L., Pique, C., Pham, D, Tursz, T., and Dokhelar, M. C. (1994). Identification of functional regions in the human T-cell leukemia virus type I SU glycoprotein. J. Virol. 68, 3544-3549.

Delamarre, L., Rosenberg, A. R., Pique, C., Pham, D., Callebaut, I., and Dokhelar, M. C. (1996). The HTLV-I envelope glycoproteins: structure and functions. J. Acquir. Immune Defic. Syndr. Hum. Retrovirol. 13(Suppl. 1), S85-S91.
Derse, D., Hill, S. A., Lloyd, P. A., Chung, H. K., and Morse, B. A. (2001). Examining human T-lymphotropic virus type 1 infection and replication by cell-free infection with recombinant virus vectors. J. Virol. 75, 8461-8468

Desgranges, C., Souche, S., Vernant, J. C., Smadja, D., Vahlne, A., and Horal, P. (1994). Identification of novel neutralization-inducing regions of the human $T$ cell lymphotropic virus type I envelope glycoproteins with human HTLV-I-seropositive sera. AIDS Res. Hum. Retroviruses 10, 163-173.

Edlich, R. F., Arnette, J. A., and Williams, F. M. (2000). Global epidemic of human T-cell lymphotropic virus type-I (HTLV-I). J. Emerg. Med. 18, 109-119.

Fan, N., Gavalchin, J., Paul, B., Wells, K. H., Lane, M. J., and Poiesz, B. J. (1992). Infection of peripheral blood mononuclear cells and cell lines by cell-free human T-cell lymphoma/leukemia virus type I. J. Clin. Microbiol. 30, 905-910.

Fang, D., Haraguchi, Y., Jinno, A., Soda, Y., Shimizu, N., and Hoshino, H. (1999). Heat shock cognate protein 70 is a cell fusion-enhancing factor but not an entry factor for human T-cell lymphotropic virus type I. Biochem. Biophys. Res. Commun. 261, 357-363.

Felber, B. K., Paskalis, H., KleinmanEwing, C., Wong-Staal, F., and Pavlakis, G. N. (1985). The pX protein of HTLV-I is a transcriptional activator of its long terminal repeats. Science 229, 675-679.

Feuer, G., and Green, P. L. (2005). Comparative biology of human Tcell lymphotropic virus type 1 (HTLV-1) and HTLV-2. Oncogene 24, 5996-6004.

Fujisawa, J., Seiki, M., Kiyokawa, T., and Yoshida, M. (1985). Functional activation of the long terminal repeat of human T-cell leukemia virus type I by a trans-acting factor. Proc. Natl. Acad. Sci. U.S.A. 82, 2277-2281.

Fukushima, Y., Takahashi, H., Hall, W. W., Nakasone, T., Nakata, S., Song, P., Dinh Duc, D., Hien, B., Nguyen, X. Q., Ngoc Trinh, T., Nishioka, K. Kitamura, K., Komura, K., Vahlue, A., and Honda, M. (1995). Extraordinary high rate of HTLV type II seropositivity in intravenous drug abusers in South Vietnam. AIDS Res. Hum. Retroviruses 11, 637-645.

Gaudray, G., Gachon, F., Basbous, J., Biard-Piechaczyk, M., Devaux, C., and Mesnard, J. M. (2002). The complementary strand of the human T-cell leukemia virus type 1
RNA genome encodes a bZIP transcription factor that down-regulates viral transcription. J. Virol. 76, 12813-12822.

Gessain, A., Barin, F., Vernant, J. C., Gout, O., Maurs, L., Calender, A., and de The, G. (1985). Antibodies to human T-lymphotropic virus typeI in patients with tropical spastic paraparesis. Lancet 2, 407-410.

Gessain, A., Mahieux, R., and De, T. G. (1996). Genetic variability and molecular epidemiology of human and simian $\mathrm{T}$ cell leukemia/lymphoma virus type I. J. Acquir. Immune Defic. Syndr. Hum. Retrovirol. 13, S132S145.

Ghez, D., Lepelletier, Y., Jones, K. S., Pique, C., and Hermine, $\mathrm{O}$ (2010). Current concepts regarding the HTLV-1 receptor complex. Retrovirology 7, 99.

Ghez, D., Lepelletier, Y., Lambert, S., Fourneau, J. M., Blot, V., Janvier, S., Arnulf, B., van Endert, P. M., Heveker, N., Pique, C., and Hermine, O. (2006). Neuropilin-1 is involved in human T-cell lymphotropic virus type 1 entry. J. Virol. 80, 6844-6854.

Goon, P. K., Hanon, E., Igakura, T., Tanaka, Y., Weber, J. N., Taylor, G. P., and Bangham, C. R. (2002). High frequencies of Th1type $\mathrm{CD} 4(+) \mathrm{T}$ cells specific to HTLV-1 Env and Tax proteins in patients with HTLV-1-associated myelopathy/tropical spastic paraparesis. Blood 99, 3335-3341.

Gotuzzo, E., Arango, C., deq UeirozCampos, A., and Isturiz, R. E. (2000). Human T-cell lymphotropic virus-I in Latin America. Infect. Dis. Clin. North Am. 14, 211-239.

Hanon, E., Stinchcombe, J. C., Saito, M., Asquith, B. E., Taylor, G. P., Tanaka, Y., Weber, J. N., Griffiths, G. M., and Bangham, C. R. (2000a). Fratricide among CD8(+) T lymphocytes naturally infected with human $\mathrm{T}$ cell lymphotropic virus type I. Immunity 13, 657-664.

Hanon, E., Asquith, R. E., Taylor, G. P., Tanaka, Y., Weber, J. N., and Bangham, C. R. (2000b). High frequency of viral protein expression in human $\mathrm{T}$ cell lymphotropic virus type 1infected peripheral blood mononuclear cells. AIDS Res. Hum. Retroviruses 16, 1711-1715.

Hattori, S., Kiyokawa, T., Imagawa, K. Shimizu, F., Hashimura, E., Seiki, M., and Yoshida, M. (1984). Identification of gag and env gene products of human T-cell leukemia virus (HTLV). Virology 136, 338-347.

Hieshima, K., Nagakubo, D., Nakayama, T., Shirakawa, A. K., Jin, Z., and Yoshie, O. (2008). Tax-inducible 
production of CC chemokine ligand 22 by human $\mathrm{T}$ cell leukemia virus type 1 (HTLV-1)-infected T cells promotes preferential transmission of HTLV-1 to CCR4-expressing CD4+ T cells. J. Immunol. 180, 931-939.

Hildreth, J. E. (1998). Syncytiuminhibiting monoclonal antibodies produced against human T-cell lymphotropic virus type 1-infected cells recognize class II major histocompatibility complex molecules and block by protein crowding. J. Virol. 72, 9544-9552.

Hildreth, J. E., Subramanium, A., and Hampton, R. A. (1997). Human T-cell lymphotropic virus type 1 (HTLV-1)-induced syncytium formation mediated by vascular cell adhesion molecule-1: evidence for involvement of cell adhesion molecules in HTLV-1 biology. J. Virol. 71, 1173-1180.

Hino, S., Katamine, S., Kawase, K., Miyamoto, T., Doi, H., Tsuji, Y., and Yamabe, T. (1994). Intervention of maternal transmission of HTLV-1 in Nagasaki, Japan. Leukemia 8, S68S70.

Hinuma, Y., Nagata, K., Hanaoka, M., Nakai, M., Matsumoto, T., Kinoshita, K.-I., Shirakawa, S., and Miyoshi, I. (1981). Adult T-cell leukemia: antigen in an ATL cell line and detection of antibodies to the antigen in human sera. Proc. Natl. Acad. Sci. U.S.A. 78, 6476-6480.

Hjelle, B., Appenzeller, O., Mills, R., Alexander, S., Torrez-Martinez, N., Jahnke, R., and Ross, G. (1992). Chronic neurodegenerative disease associated with HTLV-II infection. Lancet 339, 645-646.

Ho, D. D., Rota, T. R., and Hirsch, M. S. (1984). Infection of human endothelial cells by human T-lymphotropic virus type I. Proc. Natl. Acad. Sci. U.S.A. 81, 7588-7590.

Hoshino, H., Shimoyama, M., Miwa, M., and Sugimura, T. (1983). Detection of lymphocytes producing a human retrovirus associated with adult $\mathrm{T}$ cell leukemia by syncytia induction assay. Proc. Natl. Acad. Sci. U.S.A. 80, 7337-7341.

Hoxie, J. A., Matthews, D. M., and Cines, D. B. (1984). Infection of human endothelial cells by human T-cell leukemia virus type I. Proc. Natl. Acad. Sci. U.S.A. 81, 7591-7595.

Ibrahim, J., Griffin, P., Coombe, D. R., Rider, C. C., and James, W. (1999). Cell-surface heparan sulfate facilitates human immunodeficiency virus type 1 entry into some cell lines but not primary lymphocytes. Virus Res. 60, 159-169.

Igakura, T., Stinchcombe, J. C., Goon, P. K., Taylor, G. P., Weber, J. N., Griffiths, G. M., Tanaka, Y., Osame, M., and Bangham, C. R. M. (2003). Spread of HTLV-I between lymphocytes by virus-induced polarization of the cytoskeleton. Science 299, 1713-1716.

Ijichi, S., Ramundo, M. B., Takahashi, H., and Hall, W. W. (1992). In vivo cellular tropism of human T-cell leukemia virus type II (HTLV-II). J. Exp. Med. 176, 293-296.

Jain, P., Manuel, S. L., Khan, Z. K., Ahuja, J., Quann, K., and Wigdahl, B. (2009). DC-SIGN mediates cellfree infection and transmission of human T-cell lymphotropic virus type 1 by dendritic cells. J. Virol. 83, 10908-10921.

Jassal, S. R., Pohler, R. G., and Brighty, D. W. (2001). Human T-cell leukemia virus type 1 receptor expression among syncytium-resistant cell lines revealed by a novel surface glycoprotein-immunoadhesin. J. Virol. 75, 8317-8328.

Jenkins, M. R., Tsun, A., Stinchcombe, J. C., and Griffiths, G. M. (2009). The strength of $\mathrm{T}$ cell receptor signal controls the polarization of cytotoxic machinery to the immunological synapse. Immunity 31 , 621-631.

Jin, Q., Agrawal, L., Van Horn-Ali, Z., and Alkhatib, G. (2006a). Infection of CD4+ $\mathrm{T}$ lymphocytes by the human $\mathrm{T}$ cell leukemia virus type 1 is mediated by the glucose transporter GLUT-1: evidence using antibodies specific to the receptor's large extracellular domain. Virology 349, 184-196.

Jin, Q., Agrawal, L., Vanhorn-Ali, Z., and Alkhatib, G. (2006b). GLUT-1-independent infection of the glioblastoma/astroglioma U87 cells by the human $\mathrm{T}$ cell leukemia virus type 1. Virology 353, 99-110.

Jin, Q., Alkhatib, B., Cornetta, K., and Alkhatib, G. (2010). Alternate receptor usage of neuropilin-1 and glucose transporter protein 1 by the human T cell leukemia virus type 1 . Virology 396, 203-212.

Jolly, C., and Sattentau, Q. J. (2005). Human immunodeficiency virus type 1 virological synapse formation in $\mathrm{T}$ cells requires lipid raft integrity. J. Virol. 79, 12088-12094.

Jones, K. S., Akel, S., Petrow-Sadowski, C., Huang, Y., Bertolette, D. C., and Ruscetti, F. W. (2005a). Induction of human $\mathrm{T}$ cell leukemia virus type I receptors on quiescent naive $\mathrm{T}$ lymphocytes by TGF-beta. J. Immunol. 174, 4262-4270.

Jones, K. S., Petrow-Sadowski, C., Bertolette, D. C., Huang, Y., and Ruscetti, F. W. (2005b). Heparan sulfate proteoglycans mediate attachment and entry of human T-cell leukemia virus type 1 virions into $\mathrm{CD} 4+\mathrm{T}$ cells. J. Virol. 79, 12692-12702.

Jones, K. S., Fugo, K., Petrow-Sadowski, C., Huang, Y., Bertolette, D. C., Lisinski, I., Cushman, S. W., Jacobson, S., and Ruscetti, F. W. (2006). Human Tcell leukemia virus type 1 (HTLV-1) and HTLV-2 use different receptor complexes to enter T cells. J. Virol. 80, 8291-8302.

Jones, K. S., Huang, Y. K., Chevalier, S. A., Afonso, P. V., PetrowSadowski, C., Bertolette, D. C., Gessain, A., Ruscetti, F. W., and Mahieux, R. (2009). The receptor complex associated with human T-cell lymphotropic virus type 3 (HTLV-3) Env-mediated binding and entry is distinct from, but overlaps with, the receptor complexes of HTLV-1 and HTLV-2. J. Virol. 83, 5244-5255.

Jones, K. S., Lambert, S., Bouttier, M. Bénit, L., Ruscetti, F. W., Hermine, O., and Pique, C. (2011). Molecular aspects of HTLV-1 entry: functional domains of the HTLV-1 surface subunit (SU) and their relationships to the entry receptors. Viruses 3, 794-810.

Jones, K. S., Petrow-Sadowski, C., Huang, Y. K., Bertolette, D. C., and Ruscetti, F. W. (2008). Cell-free HTLV-1 infects dendritic cells leading to transmission and transformation of CD4(+) T cells. Nat. Med. 14, 429-436.

Kajiyama, W., Kashiwagi, S., Ikematsu, H., Hayashi, J., Nomura, H., and Okochi, K. (1986). Intrafamilial transmission of adult $\mathrm{T}$ cell leukemia virus. J. Infect. Dis. 154, 851-857.

Kataoka, R., Takehara, N., Iwahara, Y., Sawada, T., Ohtsuki, Y., Dawei, Y., Hoshino, H., and Miyoshi, I. (1990). Transmission of HTLV-I by blood transfusion and its prevention by passive immunization in rabbits. Blood 76, 1657-1661.

Khabbaz, R. F., Onorato, I. M. Cannon, R. O., Hartley, T. M. Roberts, B., Hosein, B., and Kaplan, J. E. (1992). Seroprevalence of HTLV-1 and HTLV-2 among intravenous drug users and persons in clinics for sexually transmitted diseases. N. Engl. J. Med. 326, 375-380.

Kim, F. J., Manel, N., Garrido, E. N., Valle, C., Sitbon, M., and Battini,
J. L. (2004). HTLV-1 and -2 envelope SU subdomains and critical determinants in receptor binding. Retrovirology 1, 41.

Kim, F. J., Seiliez, I., Denesvre, C., Lavillette, D., Cosset, F. L., and Sitbon, M. (2000). Definition of an aminoterminal domain of the human $\mathrm{T}$ cell leukemia virus type 1 envelope surface unit that extends the fusogenic range of an ecotropic murine leukemia virus. J. Biol. Chem. 275, 23417-23420.

Kitajima, I., Yamamoto, K., Sato, K., Nakajima, Y., Nakajima, T., Maruyama, I., Osame, M., and Nishioka, K. (1991). Detection of human $\mathrm{T}$ cell lymphotropic virus type I proviral DNA and its gene expression in synovial cells in chronic inflammatory arthropathy. J. Clin. Invest. 88, 1315-1322.

Knight, S. C., Macatonia, S. E., Cruickshank, K., Rudge, P., and Patterson, S. (1993). Dendritic cells in HIV1 and HTLV-1 infection. Adv. Exp. Med. Biol. 329, 545-549.

Kobe, B., Center, R. J., Kemp, B. E., and Poumbourios, P. (1999). Crystal structure of human $\mathrm{T}$ cell leukemia virus type 1 gp21 ectodomain crystallized as a maltose-binding protein chimera reveals structural evolution of retroviral transmembrane proteins. Proc. Natl. Acad. Sci. U.S.A. 96, 4319-4324.

Koyanagi, Y., Itoyama, Y., Nakamura, N., Takamatsu, K., Kira, J., Iwamasa, T., Goto, I., and Yamamoto, N. (1993). In vivo infection of human T-cell leukemia virus type I in non-T cells. Virology 196, 25-33.

Kuroki, M., Nakamura, M., Itoyama, Y., Tanaka, Y., Shiraki, H., Baba, E., Esaki, T., Tatsumoto, T., Nagafuchi, S., and Nakano, S. (1992). Identification of new epitopes recognized by human monoclonal antibodies with neutralizing and antibody-dependent cellular cytotoxicity activities specific for human $\mathrm{T}$ cell leukemia virus type 1. J. Immunol. 149, 940-948.

Kusuhara, K., Sunoda, S., Takahashi, K., Tokugawa, K., Fukushige, J., and Ueda, K. (1987). Mother to child transmission of human $\mathrm{T}$ cell leukemia virus type I (HTLV-I): a fifteen year followup study in Okinawa, Japan. Int. J. Cancer 40, 755-757.

Lairmore, M. D., Anupam, R., Bowden, N., Haines, R., Haynes, R. A., Ratner, L., and Green, P. L. (2011). Molecular determinants of human T-lymphotropic virus type 1 
transmission and spread. Viruses 3, 1131-1165.

Lairmore, M. D., Silverman, L., and Ratner, L. (2005). Animal models for human T-lymphotropic virus type 1 (HTLV-1) infection and transformation. Oncogene 24, 6005-6015.

Lamb, D., Mirsaliotis, A., Kelly, S. M., and Brighty, D. W. (2009). Basic residues are critical to the activity of peptide inhibitors of human $\mathrm{T}$ cell leukemia virus type 1 entry. J. Biol. Chem. 284, 6575-6584.

Lambert, S., Bouttier, M., Vassy, R., Seigneuret, M., Petrow-Sadowski, C., Janvier, S., Heveker, N., Ruscetti, F. W., Perret, G., Jones, K. S., and Pique, C. (2009). HTLV-1 uses HSPG and neuropilin-1 for entry by molecular mimicry of VEGF165. Blood 113, 5176-5185.

Lavillette, D., Maurice, M., Roche, C., Russell, S. J., Sitbon, M., and Cosset, F. L. (1998). A proline-rich motif downstream of the receptor binding domain modulates conformation and fusogenicity of murine retroviral envelopes. J. Virol. 72, 9955-9965.

Lee, H., Swanson, P., Shorty, V. S., Zack, J. A., Rosenblatt, J. D., and Chen, I. S. Y. (1989). High rate of HTLVII infection in seropositive IV drug abusers from New Orleans. Science 244, 471-475.

Lehky, T. J., Fox, C. H., Koenig, S., Levin, M. C., Flerlage, N., Izumo, S., Sato, E., Raine, C. S., Osame, M., and Jacobson, S. (1995). Detection of human T-lymphotropic virus type I (HTLV-I) tax RNA in the central nervous system of HTLVI-associated myelopathy/tropical spastic paraparesis patients by in situ hybridization. Ann. Neurol. 37, 167-175.

Li, K., Zhang, S., Kronqvist, M., Wallin, M., Ekstrom, M., Derse, D., and Garoff, H. (2008). Intersubunit disulfide isomerization controls membrane fusion of human T-cell leukemia virus Env. J. Virol. 82, 7135-7143.

Londos-Gagliardi, D., Dalibart, R., Geoffre, S., Dalbon, P., Pouliquen, J. F., Georges-Courbot, M. C., SainteFoie, S., Hajjar, C., Georges, A. J., Moreau, J. P., and Guillemain, B. (1996). Immunogenicity of variable regions of the surface envelope glycoprotein of HTLV type I and identification of new major epitopes in the 239-261 region. AIDS Res. Hum. Retroviruses 12, 941-950.

Macatonia, S. E., Cruickshank, J. K., Rudge, P., and Knight, S. C. (1992). Dendritic cells from patients with tropical spastic paraparesis are infected with HTLV-1 and stimulate autologous lymphocyte proliferation. AIDS Res. Hum. Retroviruses 8, 1699-1706.

Maerz, A. L., Center, R. J., Kemp, B. E., Kobe, B., and Poumbourios, P. (2000). Functional implications of the human T-lymphotropic virus type 1 transmembrane glycoprotein helical hairpin structure. J. Virol. 74, 6614-6621.

Mahieux, R., and Gessain, A. (2009). The human HTLV-3 and HTLV4 retroviruses: new members of the HTLV family. Pathol. Biol. 57, 161-166.

Majorovits, E., Nejmeddine, M., Tanaka, Y., Taylor, G. P., Fuller, S. D., and Bangham, C. R. (2008). Human Tlymphotropic virus-1 visualized at the virological synapse by electron tomography. PLoS ONE 3, e2251. doi:10.1371/journal.pone.0002251

Manel, N., Battini, J. L., Taylor, N., and Sitbon, M. (2005a). HTLV-1 tropism and envelope receptor. Oncogene 24, 6016-6025.

Manel, N., Battini, J. L., and Sitbon, M. (2005b). Human T cell leukemia virus envelope binding and virus entry are mediated by distinct domains of the glucose transporter GLUT1. J. Biol. Chem. 280, 29025-29029.

Manel, N., Kinet, S., Battini, J. L., Kim, F. J., Taylor, N., and Sitbon, M. (2003a). The HTLV receptor is an early T-cell activation marker whose expression requires de novo protein synthesis. Blood 101, 1913-1918.

Manel, N., Kim, F. J., Kinet, S., Taylor, N., Sitbon, M., and Battini, J. L. (2003b). The ubiquitous glucose transporter GLUT-1 is a receptor for HTLV. Cell 115, 449-459.

Marsh, M., and Helenius, A. (2006). Virus entry: open sesame. Cell 124, 729-740.

Matsuoka, M., and Jeang, K. T. (2011). Human T-cell leukemia virus type 1 (HTLV-1) and leukemic transformation: viral infectivity, Tax, HBZ and therapy. Oncogene 30, 1379-1389.

Mazurov, D., Heidecker, G., and Derse, D. (2006). HTLV-1 Gag protein associates with CD82 tetraspanin microdomains at the plasma membrane. Virology 346, 194-204.

Mazurov, D., Ilinskaya, A., Heidecker, G., Lloyd, P., and Derse, D. (2010). Quantitative comparison of HTLV1 and HIV-1 cell-to-cell infection with new replication dependent vectors. PLoS Pathog. 6, e1000788. doi:10.1371/journal.ppat.1000788

Mirsaliotis, A., Lamb, D., and Brighty, D. W. (2008). Nonhelical leash and $\alpha$-helical structures determine the potency of a peptide antagonist of human T-cell leukemia virus entry. J. Virol. 82, 4965-4973.

Mirsaliotis, A., Nurkiyanova, K., Lamb, D., Woof, J. M., and Brighty, D. W. (2007). Conformation-specific antibodies targeting the trimer-ofhairpins motif of the human T-cell leukemia virus type 1 transmembrane glycoprotein recognize the viral envelope but fail to neutralize viral entry. J. Virol. 81, 6019-6031.

Moriuchi, M., and Moriuchi, H. (2002). Transforming growth factor-beta enhances human T-cell leukemia virus type I infection. J. Med. Virol. 67, 427-430.

Mothes, W., Boerger, A. L., Narayan, S., Cunningham, J. M., and Young, J. A. (2000). Retroviral entry mediated by receptor priming and low $\mathrm{pH}$ triggering of an envelope glycoprotein. Cell 103, 679-689.

Murphy, E. L., Figueroa, J. P., Gibbs, W. N., Brathwaite, A., Holding, C. M., Waters, D., Cranston, B., Hanchard, B., and Blattner, W. A. (1989). Sexual transmission of human T-lymphotropic virus type I (HTLV-I). Ann. Intern. Med. 111 555-560.

Nagai, M., Brennan, M. B., Sakai, J. A., Mora, C. A., and Jacobson, S. (2001). CD8 (+) T cells are an in vivo reservoir for human T-cell lymphotropic virus type I. Blood 98, 1858-1861.

Nagy, K., Clapham, P., CheingsongPopov, R., and Weiss, R. A. (1983). Human T-cell leukemia virus type I: induction of syncytia and inhibition by patients' sera. Int. J. Cancer 32 , 321-328.

Nakamura, H., Hayami, M., Ohta, Y., Ishikawa, K., Tsujimoto, H., Kiyokawa, T., Yoshida, M., Sasagawa, A., and Honjo, S. (1987). Protection of cynomolgus monkeys against infection by human T-cell leukemia virus type- 1 by immunization with viral env gene products produced in Escherichia coli. Int. J. Cancer 40, 403-407.

Nath, M. D., Ruscetti, F. W., PetrowSadowski, C., and Jones, K. S. (2003). Regulation of the cellsurface expression of an HTLV-I binding protein in human $\mathrm{T}$ cells during immune activation. Blood 101, 3085-3092.

Nejmeddine, M., Barnard, A. L., Tanaka, Y., Taylor, G. P., and Bangham, C. R. M. (2005). Human T lymphotropic virus, type 1, tax protein triggers microtubule reorientation in the virological synapse. J. Biol. Chem. 280, 29653-29660.
Nejmeddine, M., Negi, V. S., Mukherjee, S., Tanaka, Y., Orth, K., Taylor, G. P., and Bangham, C. R. M. (2009). HTLV-1-Tax and ICAM-1 act on T-cell signal pathways to polarize the microtubule-organizing center at the virological synapse. Blood 114 1016-1025.

Nicot, C., Harrod, R. L., Ciminale, V., and Franchini, G. (2005). Human Tcell leukemia/lymphoma virus type 1 nonstructural genes and their functions. Oncogene 24, 6026-6034.

Okuma, K., Dalton, K. P., Buonocore, L., Ramsburg, E., Rose, J. K. (2003). Development of a novel surrogate virus for human T-cell leukemia virus type 1: inhibition of infection by osteoprotegerin. J. Virol. 77, 8562-8569.

Osame, M., and Igata, A. (1989). The history of discovery and clinicoepidemiology of HTLV-I-associated myelopathy (HAM). Jpn. J. Med. 28, 412-414.

Osame, M., Usuku, K., Izumo, S., Ijichi, N., Amitani, H., Igata, A., Matsumoto, M., and Tara, M. (1986). HTLV-I associated myelopathy, a new clinical entity. Lancet 1, 1031-1032.

Pais-Correia, A. M., Sachse, M., Guadagnini, S., Robbiati, V., Lasserre, R., Gessain, A., Gout, O., Alcover, A., and Thoulouze, M. I. (2009). Biofilm-like extracellular viral assemblies mediate HTLV-1 cell-to-cell transmission at virological synapses. Nat. Med. 16, 83-89.

Palker, T. J., Riggs, E. R., Spragion, D. E., Muir, A. J., Scearce, R. M., Randall, R. R., McAdams, M. W., McKnight, A., Clapham, P., and Weiss, R. A. (1992). Mapping of homologous, amino-terminal neutralizing regions of human $\mathrm{T}$-cell lymphotropic virus type I and II gp46 envelope glycoproteins. J. Virol. 66, 5879-5889.

Pinon, J. D., Klasse, P. J., Jassal, S. R., Welson, S., Weber, J., Brighty, D. W., and Sattentau, Q. J. (2003a). Human T-cell leukemia virus type 1 envelope glycoprotein gp46 interacts with cell surface heparan sulfate proteoglycans. J. Virol. 77, 9922-9930.

Pinon, J. D., Kelly, S. M., Price, N. C., Flanagan, J. U., and Brighty, D. W. (2003b). An antiviral peptide targets a coiled-coil domain of the human T-cell leukemia virus envelope glycoprotein. J. Virol. 77, 3281-3290.

Pinter, A., Kopelman, R., Li, Z., Kayman, S. C., and Sanders, D. A (1997). Localization of the labile 
disulfide bond between SU and TM of the murine leukemia virus envelope protein complex to a highly conserved CWLC motif in SU that resembles the active-site sequence of thiol-disulfide exchange enzymes. J. Virol. 71, 8073-8077.

Pique, C., Lagaudriere-Gesbert, C., Delamarre, L., Rosenberg, A. R., Conjeaud, H., and Dokhelar, M. C. (2000). Interaction of CD82 tetraspanin proteins with HTLV-1 envelope glycoproteins inhibits cellto-cell fusion and virus transmission. Virology 276, 455-465.

Pique, C., Pham, D., Tursz, T., and Dokhelar, M. C. (1992). Human Tcell leukemia virus type I envelope protein maturation process: requirements for syncytium formation. $J$. Virol. 66, 906-913.

Poiesz, B. J., Ruscetti, F. W., Gazdar, A. F., Bunn, P. A., Minna, J. D., and Gallo, R. C. (1980). Detection and isolation of type $C$ retrovirus particles from fresh and cultured lymphocytes of a patient with cutaneous T-cell lymphoma. Proc. Natl. Acad. Sci. U.S.A. 77, 7415-7419.

Proietti, F. A., Carneiro-Proietti, A. B., Catalan-Soares, B. C., and Murphy, E. L. (2005). Global epidemiology of HTLV-I infection and associated diseases. Oncogene 24, 6058-6068.

Richardson, J. H., Edwards, A. J., Cruickshank, J. K., Rudge, P., Dalgleish, A. G. (1990). In vivo cellular tropism of human T-cell leukemia virus type 1. J. Virol. 64, 5682-5687.

Romeo, P. H., Lemarchandel, V., and Tordjman, R. (2002). Neuropilin-1 in the immune system. Adv. Exp. Med. Biol. 515, 49-54.

Sawada, T., Iwahara, Y., Ishii, K., Taguchi, H., Hoshino, H., and Miyoshi, I. (1991). Immunoglobulin prophylaxis against milkborne transmission of human $\mathrm{T}$ cell leukemia virus type 1 in rabbits. J. Infect. Dis. 164, 1193-1196.

Saxinger, W., Blattner, W. A., Levine, P. H., Clark, J., Biggar, R., Hoh, M., Moghissi, J., Jacobs, P., Wilson, L., Jacobson, R., Crookes, R., Strong, M., Angari, A. A., Dean, A. G., Nkrumah, F. K., Mourali, N., and Gallo, R. C. (1984). Human T-cell leukemia virus (HTLV-I) antibodies in Africa. Science 225, 1473-1476.

Seiki, M., Hattori, S., Hirayama, Y., and Yoshida, M. (1983). Human adult T-cell leukemia virus: complete nucleotide sequence of the provirus genome integrated in leukemia cell DNA. Proc. Natl. Acad. Sci. U.S.A. 80, 3618-3622.
Setoyama, M., Kerdel, F. A., Elgart, G., Kanzaki, T., and Byrnes, J. J. (1998). Detection of HTLV-1 by polymerase chain reaction in situ hybridization in adult T-cell leukemia/lymphoma. Am. J. Pathol. 152, 683-689.

Shinagawa, M., Jinno-Oue, A., Shimizu, N., Roy, B. B., Shimizu, A., Hoque, S. A., and Hoshino, H. (2012). Human T-cell leukemia viruses are highly unstable over a wide range of temperatures. J. Gen. Virol. 93. 608-617.

Shintani, Y., Takashima, S., Asano, Y., Kato, H., Liao, Y., Yamazaki, S., Tsukamoto, O., Seguchi, O., Yamamoto, H., Fukushima, T., Sugahara, K., Kitakaze, M., and Hori, M. (2006). Glycosaminoglycan modification of neuropilin-1 modulates VEGFR2 signaling. EMBO J. 25, 3045-3055.

Shukla, D., Liu, J., Blaiklock, P., Shworak, N. W., Bai, X., Esko, J. D., Cohen, G. H., Eisenberg, R. J., Rosenberg, R. D., and Spear, P. G. (1999). A novel role for 3-O-sulfated heparan sulfate in herpes simplex virus 1 entry. Cell 99, 13-22.

Silverman, L. R., Phipps, A. J., Montgomery, A., Ratner, L., and Lairmore, M. D. (2004). Human Tcell lymphotropic virus type 1 open reading frame II-encoded p30II is required for in vivo replication: evidence of in vivo reversion. J. Virol. 78, 3837-3845.

Sodroski, J. G., Rosen, C. A., and Haseltine, W.A. (1984). Trans-acting transcriptional activation of the long terminal repeat of human $\mathrm{T}$ lymphotropic viruses in infected cells. Science 223, 381-385.

Soker, S., Takashima, S., Miao, H. Q., Neufeld, G., and Klagsbrun, M. (1998). Neuropilin-1 is expressed by endothelial and tumor cells as an isoform-specific receptor for vascular endothelial growth factor. Cell 92, 735-745.

Sonoda, S., Li, H. C., and Tajima, K. (2011). Ethnoepidemiology of HTLV-1 related diseases: ethnic determinants of HTLV-1 susceptibility and its worldwide dispersal. Cancer Sci. 102, 295-301.

Sutton, R. E., and Littman, D. R. (1996). Broad host range of human T-cell leukemia virus type 1 demonstrated with an improved pseudotyping system. J. Virol. 70, 7322-7326.

Suzuki, M., Matsuoka, H., Yamashita, K., Maeda, K., Kawano, K., Uno, H., and Tsubouchi, H. (1998). CD45RO expression on peripheral lymphocytes as a prognostic marker for adult T-cell leukemia. Leuk. Lymphoma 28, 583-590.

Takatsuki, K. (2005). Discovery of adult T-cell leukemia. Retrovirology 2, 16.

Tanaka, A., Jinno-Oue, A., Shimizu, N., Hoque, A., Mori, T., Islam, S., Nakatani, Y., Shinagawa, M., and Hoshino, H. (2012). Entry of human T-cell leukemia virus type 1 is augmented by heparan sulfate proteoglycans bearing short heparin-like structures. J. Virol. 86, 2959-2969.

Tanaka, Y., Fukudome, K., Hayashi, M. Takagi, S., and Yoshie, O. (1995). Induction of ICAM-1 and LFA-3 by Taxl of human T-cell leukemia virus type 1 and mechanism of downregulation of ICAM-1 or LFA-1 in adult $\mathrm{T}$ cell leukemia cell lines. Int. J. Cancer 60, 554-561.

Tanaka, Y., Tanaka, R., Terada, E., Koyanagi, Y., Miyanokurosaki, N., Yamamoto, N., Baba, E., Nakamura, M., and Shida, H. (1994). Induction of antibody responses that neutralize human T-cell leukemia virus type I infection in vitro and in vivo by peptide immunization. J. Virol. 68 , 6323-6331.

Tanaka, Y., Zeng, L., Shiraki, H., Shida, H., and Tozawa, H. (1991). Identification of a neutralization epitope on the envelope gp46 antigen of human T-cell leukemia virus type I and induction of neutralizing antibody by peptide immunization. $J$. Immunol. 147, 354-360.

Tordjman, R., Lepelletier, Y., Lemarchandel, V., Cambot, M., Gaulard, P., Hermine, O., and Romeo, P. H. (2002). A neuronal receptor, neuropilin-1, is essential for the initiation of the primary immune response. Nat. Immunol. 3, 477-482.

Toulza, F., Nosaka, K., Takiguchi, M., Pagliuca, T., Mitsuya, H., Tanaka, Y., Taylor, G. P., and Bangham, C. R. (2009). FoxP3+ regulatory $\mathrm{T}$ cells are distinct from leukemia cells in HTLV-1-associated adult Tcell leukemia. Int. J. Cancer 125 , 2375-2382.

Trejo, S. R., and Ratner, L. (2000). The HTLV receptor is a widely expressed protein. Virology 268, 41-48.

Uchiyama, T. (1997). Human T cell leukemia virus type I (HTLV-I) and human diseases. Annu. Rev. Immunol. 15, 15-37.

Uemura, Y., Kotani, S., Yoshimoto, S., Fujishita, M., Yamashita, M., Ohtsuki, Y., Taguchi, H., and Miyoshi, I. (1987). Mother-to-offspring transmission of human $\mathrm{T}$ cell leukemia virus type I in rabbits. Blood 69, 1255-1258.
Ureta-Vidal, A., Angelin-Duclos, C., Tortevoye, P., Murphy, E., Lepere, J. F., Buigues, R. P., Jolly, N., Joubert, M., Carles, G., Pouliquen, J. F., de The, G., Moreau, J. P., and Gessain, A. (1999). Mother-tochild transmission of human T-cellleukemia/lymphoma virus type I: implication of high antiviral antibody titer and high proviral load in carrier mothers. Int. J. Cancer 82, 832-836.

van Prooyen, N., Gold, H., Andresen, V., Schwartz, O., Jones, K., Ruscetti, F., Lockett, S., Gudla, P., Venzon, D., and Franchini, G. (2010). Human T-cell leukemia virus type 1 p8 protein increases cellular conduits and virus transmission. Proc. Natl. Acad. Sci. U.S.A. 107, 20738-20743.

Wallin, M., Ekstrom, M., and Garoff, H. (2004). Isomerization of the intersubunit disulphide-bond in Env controls retrovirus fusion. $E M B O \mathrm{~J}$. 23, 54-65.

Walter, M. J., Lehky, T. J., Fox, C. H., and Jacobson, S. (1994). In situ PCR for the detection of HTLV-I in HAM/TSP patients. Ann. N. Y. Acad. Sci. 724, 404-413.

Wielgosz, M. M., Rauch, D. A., Jones, K. S., Ruscetti, F. W., and Ratner, L. (2005). Cholesterol dependence of HTLV-I infection. AIDS Res. Hum. Retroviruses 21, 43-50.

Wilson, K. A., Bär, S., Maerz, A. L., Alizon, M., and Poumbourios, P. (2005). The conserved glycinerich segment linking the $\mathrm{N}$-terminal fusion peptide to the coiled coil of human T-cell leukemia virus type 1 transmembrane glycoprotein gp21 is a determinant of membrane fusion function. J. Virol. 79, 4533-4539.

Wucherpfennig, K. W., Hollsberg, P., Richardson, J. H., Benjamin, D., and Hafler, D. A. (1992). T-cell activation by autologous human T-cell leukemia virus type I-infected T-cell clones. Proc. Natl. Acad. Sci. U.S.A. 89, 2110-2114.

Yanagihara, R., Jenkins, C. L., Alexander, S. S., Mora, C. A., and Garruto, R. M. (1990). Human T lymphotropic virus type I infection in Papua New Guinea: high prevalence among the Hagahai confirmed by western analysis. J. Infect. Dis. 162, 649-654.

Yano, H., Ishida, T., Inagaki, A., Ishii, T., Kusumoto, S., Komatsu, H., Iida, S., Utsunomiya, A., and Ueda, R. (2007). Regulatory T-cell function of adult T-cell leukemia/lymphoma 
cells. Int. J. Cancer 120, 2052-2057.

Yoshida, M., Miyoshi, I., and Hinuma, Y. (1982). Isolation and characterization of retrovirus from cell lines of human adult T-cell leukemia and its implication in the disease. Proc. Natl. Acad. Sci. U.S.A. 79, 2031-2035.

Yoshikura, H., Nishida, J., Yoshida, M., Kitamura, Y., Takaku, F., and Ikeda,
S. (1984). Isolation of HTLV derived from Japanese adult T-cell leukemia patients in human diploid fibroblast strain IMR90 and the biological characters of the infected cells. Int. J. Cancer 33, 745-749.

Conflict of Interest Statement: The author declares that the research was conducted in the absence of any commercial or financial relationships that could be construed as a potential conflict of interest.

Received: 10 March 2012; accepted: 30 May 2012; published online: 21 June 2012.

Citation: Hoshino H (2012) Cellular factors involved in HTLV-1 entry and pathogenicity. Front. Microbio. 3:222. doi: 10.3389/fmicb.2012.00222
This article was submitted to Frontiers in Virology, a specialty of Frontiers in Microbiology.

Copyright () 2012 Hoshino. This is an open-access article distributed under the terms of the Creative Commons Attribution Non Commercial License, which permits non-commercial use, distribution, and reproduction in other forums, provided the original authors and source are credited. 